\title{
Epidemic diffusion of KPC carbapenemase-producing Klebsiella pneumoniae in Italy: results of the first countrywide survey, 15 May to 30 June 2011
}

T Giani ${ }^{1}$, B Pini ${ }^{2}$, F Arena ${ }^{1}$, V Conte ${ }^{1}$, S Bracco ${ }^{2}$, R Migliavacca $^{3}$, the AMCLI-CRE Survey Participants ${ }^{4}$, A Pantosti ${ }^{5}$, L Pagani $^{3}$,

F Luzzaro' ${ }^{2}$ G M Rossolini (gianmaria.rossolini@unisi.it) ${ }^{1,6,7}$

1. Department of Medical Biotechnologies, University of Siena, Siena, Italy

2. Microbiology and Virology Unit, A. Manzoni Hospital, Lecco, Italy

3. Department of Clinical Surgical Diagnostic and Pediatric Sciences, Section of Microbiology, University of Pavia, Pavia, Italy

4. The AMCLI-CRE Survey Participants are listed at the end of this article

5. Department of Infectious, Parasitic and Immune-Mediated Diseases, Italian National Health Institute, Rome, Italy

6. Department of Experimental and Clinical Medicine, University of Florence, Italy

7. Clinical Microbiology and Virology Unit, Department of Laboratory Medicine, Careggi University Hospital, Florence, Italy

Citation style for this article:
Giani T, Pini B, Arena F, Conte V, Bracco S, Migliavacca R, the AMCLI-CRE Survey Participants, Pantosti A, Pagani L, Luzzaro F, Rossolini GM. Epidemic

diffusion of KPC carbapenemase-producing Klebsiella pneumoniae in Italy: results of the first countrywide survey, 15 May to 30 June 2011 . Euro Surveill.

2013;18(22):pii=20489. Available online: $\mathrm{http}: / /$ www.eurosurveillance.org/ViewArticle.aspx?Articleld=20489

Article submitted on 07 September 2012 /published on 30 May 2013

Carbapenem-resistant Enterobacteriaceae (CRE) are emerging as a public health problem in various settings. In Italy, a rapid and remarkable increase of carbapenem-non-susceptible Klebsiella pneumoniae has been reported since 2010. Here we report on the results of a countrywide cross-sectional survey, carried out from 15 May to 30June 2011 to investigate the diffusion of CRE in Italy and to characterise the most prevalent resistance mechanisms and their dissemination patterns. CRE were reported from most ( 23 of 25 ) participating laboratories, with an overall proportion of $3.5 \%$ and $0.3 \%$ among consecutive non-duplicate clinical isolates of Enterobacteriaceae from inpatients $(n=7,154)$ and outpatients $(n=6,595)$, respectively. $K$. pneumoniae was the most frequent species (proportion of carbapenem-non-susceptible isolates: $11.9 \%$ ), while a minority of CRE of other species were detected. Carbapenemase production was detected in the majority $(85 \%)$ of CRE. KPC-type enzymes were by far the most common $(89.5 \%$ of carbapenemase producers), followed by VIM-1 (9.2\%) and OXA-48 (1.3\%). KPCproducing $K$. pneumoniae (KPC-KP) were detected in most centres and contributed majorly to the epidemic dissemination of CRE recently observed in our country. Dissemination of KPC-KP was mostly sustained by strains of clonal complex 258 (ST-258 producing KPC-2 or KPC-3, and $\mathrm{ST}-512$ producing $\mathrm{KPC}-3$ ), while a minority belonged to ST-101.

\section{Introduction}

The increasing resistance to carbapenems among Enterobacteriaceae has become a public health problem of major concern [1,2]. Carbapenem-resistant Enterobacteriaceae (CRE) usually exhibit complex multidrug resistance phenotypes that leave very few therapeutic options $[3,4]$, and infections caused by CRE are associated with increased morbidity and mortality in comparison with those caused by carbapenem-susceptible strains ( $72 \%$ versus $22 \%$ ) [5].

At least two mechanisms can be responsible for acquired carbapenem resistance in Enterobacteriaceae: (i) reduced outer membrane permeability by porin loss in combination with the production of an extendedspectrum beta-lactamase (ESBL) or of AmpC-type betalactamase; and (ii) production of beta-lactamases capable of hydrolysing carbapenems (carbapenemases) [2]. While the former mechanism is a result of mutation and has a low overall propensity to disseminate, acquired carbapenemases are encoded by transferable genes that can disseminate among different strains and different species, and carbapenemase production is the leading carbapenem resistance mechanism in Enterobacteriaceae $[2,6,7]$. Several types of acquired carbapenemases have been detected in CRE, with KPC-, VIM-, NDM- and OXA-48-type enzymes being the most prevalent, although with a notable geographical variability $[2,6-9]$.

In Europe, individual cases or outbreaks of CRE have been reported in several countries [6] but data from the EARS-NET database show that, until 2009, the proportion of CRE has remained overall low in most countries except Greece and Cyprus, where high-level endemicity of carbapenem-nonsuscetible Klebsiella pneumoniae has been reported since the mid-2000s [10]. In Italy, sporadic cases or outbreaks caused by CRE of various species and with different resistance mechanisms have been reported since the early 2000 s [11-24], but only since 2010 an abrupt and notable increase in the proportion of carbapenem-non-susceptible K. pneumoniae has ben reported by the EARS-NET surveillance system 


\section{FIGURE 1}

Location of the laboratories participating in the survey on carbapenem-resistant Enterobacteriaceae, Italy, 15 May-30 June $2011(n=25)$

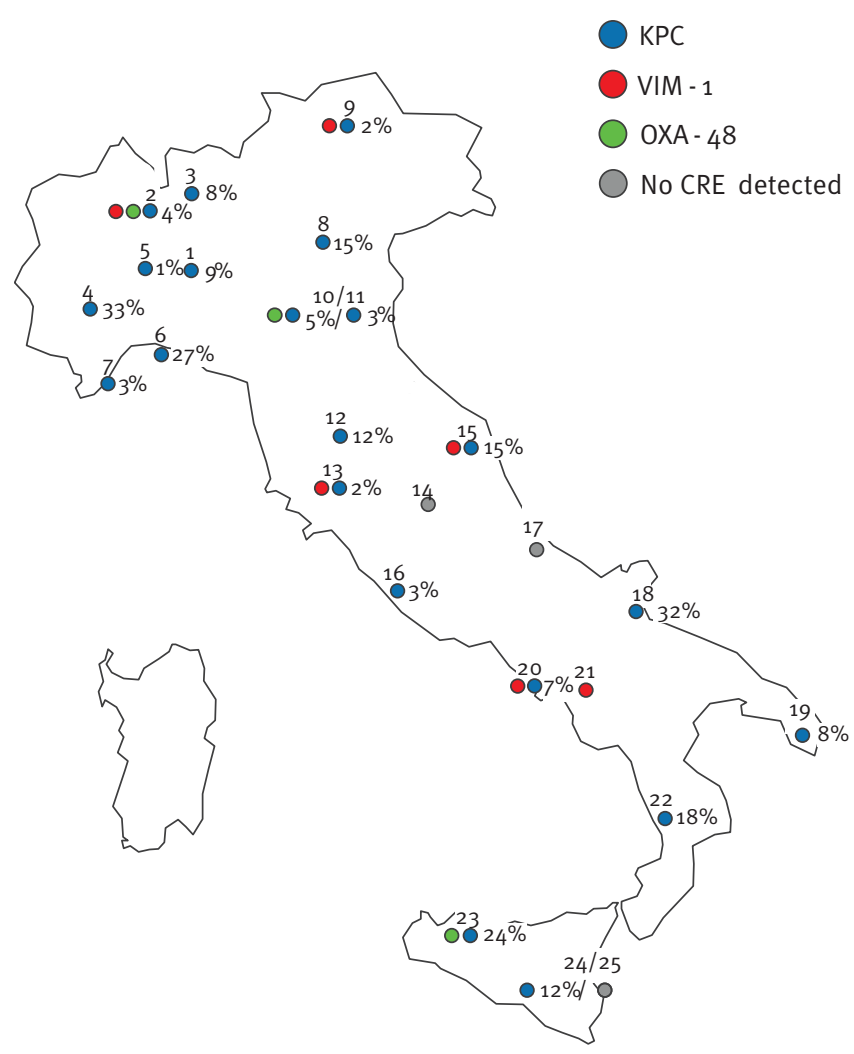

1: Milan; 2: Varese; 3: Lecco; 4: Turin; 5: Novara; 6: Genoa; 7: Sanremo; 8: Verona; 9: Bolzano; 10-11: Modena; 12: Florence; 13: Siena; 14: Perugia; 15: Ancona; 16: Rome; 17: Pescara; 18: San Giovanni Rotondo; 19: Lecce; 20: Naples; 21: Avellino; 22: Cosenza; 23: Palermo; 24-25: Catania. The types of carbapenemases detected in different laboratories, and the proportion of KPC-producing Klebsiella pneumoniae versus the total number of $K$. pneumoniae isolates are indicated.

[10]. This trend has recently been confirmed by data from the Micronet sentinel surveillance network [25]. However, the resistance mechanisms responsible for this increase have not been investigated.

In this work we report the results of a countrywide cross-sectional survey promoted by the Italian Society of Clinical Microbiologists (AMCLI) and carried out in mid-2011, to investigate the diffusion of CRE in Italy and to characterise the most prevalent resistance mechanisms and their dissemination patterns. Results confirmed that CRE have reached epidemic dissemination in Italy, and revealed that this condition was mostly related with the clonal diffusion of $K$. pneumoniae producing KPC-type carbapenemases (KPC-KP) of clonal complex (CC) 258.

\section{Methods}

Study design

Twenty-five large clinical microbiology laboratories from 23 Italian cities, distributed across the national territory and covering most Italian regions, participated in the study (Figure 1). During the period from 15 May to 30 June 2011, each laboratory collected consecutive non-replicate clinical isolates of Enterobacteriaceae, from any site of infection, that exhibited minimum inhibitory concentrations (MICs) for imipenem and/or meropenem and/or ertapenem higher than $1 \mathrm{mg} / \mathrm{L}$ (for isolates of Proteeae, i. e. Morganella morganii, Proteus spp. and Providencia spp., only meropenem and ertapenem MICs were considered). The collected isolates were transferred to reference laboratories for confirmation of species identification and carbapenem MICs, and for characterisation of the carbapenem resistance mechanisms and analysis of clonal relatedness. For each isolate, information on the clinical specimen and type of ward (in case of isolates from inpatients) were provided. Moreover, each participating laboratory provided information on the total number of consecutive non- duplicate clinical isolates of Enterobacteriaceae observed during the collection period.

\section{Characterisation of bacterial isolates}

and of resistance determinants

Bacterial identification and antimicrobial susceptibility testing were carried out by the collecting laboratories using either the Phoenix Automated Microbiology System (Becton Dickinson Diagnostic Systems, Sparks, United States) or the Vitek-2 System (bioMérieux, Marcy l'Etoile, France). Confirmatory identification was carried out by Matrix-assisted laser desorption ionisation - time of the flight (MALDI-TOF) mass spectrometry (Vitek-MS, bioMérieux). Confirmatory MIC testing for imipenem, meropenem and ertapenem was carried out by Etest (bioMérieux). All collected isolates confirmed to be non-susceptible to imipenem (not considered for Proteeae) and/or meropenem and/or ertapenem according to the EUCAST breakpoints [26] were considered as CRE for the purposes of this study. For KPC-KP, MICs of colistin, tigecycline and gentamicin were determined by the reference broth microdilution method [27], and results were interpreted according to the EUCAST breakpoints [26].

CRE were evaluated for carbapenemase production by meropenem plus EDTA and meropenem plus phenylboronic acid using the disk diffusion method $[28,29]$, and for the presence of the most common carbapenemase genes ( $\mathrm{bla}_{\mathrm{KPC}^{-}}$, bla $\mathrm{VIM}^{-}, \mathrm{bla}_{\mathrm{NDM}^{-}}, \mathrm{bla}_{\mathrm{OXA}-48^{-}}$type) by dotblot hybridisation [30]. PCR amplification [13,31-33] and sequencing of PCR amplicons were used to identify the carbapenemase genes detected by hybridisation. All CRE isolates testing negative in disk diffusion test and/or in hybridisation assays were further investigated for production of carbapenemase activity by modified Hodge test [34] and by spectrophotometric assay with crude extracts [35]. 
Proportions of carbapenem-non-susceptible Enterobacteriaceae detected in the first countrywide survey, Italy, 15 May-30 June $2011(n=13,749)$

\begin{tabular}{|c|c|c|c|c|c|c|}
\hline \multirow[t]{2}{*}{ Species } & \multicolumn{2}{|c|}{ Isolates from inpatients } & \multicolumn{2}{|c|}{ Isolates from outpatients } & \multicolumn{2}{|c|}{ All isolates } \\
\hline & Total & CRE (\%) & Total & CRE (\%) & Total & CRE (\%) \\
\hline Escherichia coli & 3,844 & $4(0.10)$ & 4,765 & $1(0.02)$ & 8,609 & $5(0.06)$ \\
\hline Klebsiella pneumoniae & 1,346 & $219(16.3)$ & 618 & $15(2.4)$ & 1,964 & 234 (11.9) \\
\hline Klebsiella oxytoca & 203 & 0 & 116 & $1(0.86)$ & 319 & $1(0.31)$ \\
\hline Enterobacter cloacae & 361 & $15(4.2)$ & 144 & 0 & 505 & $15(3.0)$ \\
\hline Enterobacter aerogenes & 147 & $4(2.7)$ & 68 & $2(2.9)$ & 215 & $6(2.8)$ \\
\hline Serratia marcescens & 117 & $4(3.4)$ & 39 & $1(2.6)$ & 156 & $5(3.2)$ \\
\hline Proteus mirabilis & 624 & $1(0.16)$ & 491 & 0 & 1,115 & $1(0.09)$ \\
\hline Citrobacter freundii & 79 & 0 & 56 & $1(1.8)$ & 135 & $1(0.74)$ \\
\hline Hafnia alvei & 24 & $2(8.3)$ & 8 & 0 & 32 & $2(6.2)$ \\
\hline Other species & 409 & 0 & 290 & 0 & 699 & 0 \\
\hline Total & 7,154 & 249 (3.5) & 6,595 & $21(0.32)$ & 13,749 & $270(2.0)$ \\
\hline
\end{tabular}

CRE: carbapenem-resistant Enterobacteriaceae.

All collected isolates confirmed to be non-susceptible to imipenem (not considered for Proteeae) and/or meropenem and/or ertapenem according to the EUCAST breakpoints [26] were considered as CRE for the purposes of this study.

Analysis of clonal relatedness

Genotyping of K. pneumoniae isolates by pulsed-field gel electrophoresis (PFGE) profiling of genomic DNA was carried out after digestion with Xbal with a CHEFDRIII apparatus (Bio-Rad, Hemel Hempstead, United Kingdom) [36], and results interpreted as recommended by Van Belkum et al. [37]. Multi-locus sequence typing (MLST) of $K$. pneumoniae isolates was performed as previously described [38], and sequence types (STs) were assigned using the MLST web site [39].

\section{Results}

Proportions of carbapenem-resistant Enterobacteriaceae from inpatients and outpatients in Italy

During the study period (15 May-30 June 2011), a total of 13,749 consecutive non-replicate clinical isolates of Enterobacteriaceae were isolated at the 25 Italian laboratories participating in the survey. Overall, 270 isolates $(2.0 \%)$ were confirmed as CRE. The proportion of CRE was approximately 10 -fold higher among isolates from inpatients (3.5\%) than among those from outpatients (0.3\%) (Table 1).

Proportions of CRE in different species are shown in Table 1. K. pneumoniae was the most affected species (proportion: $11.9 \%$ ) and contributed to the majority of CRE (234 of 270, 86.7\%). Lower CRE proportions, but still higher than $2 \%$, were observed among Enterobacter spp., Serratia marcescens, and Hafnia alvei. In Escherichia coli the proportion of CRE was very low (0.06\%).

CRE were reported from 23 of the 25 participating laboratories (Figure 1). Carbapenem-nonsusceptible isolates of $K$. pneumoniae were detected at any of these 23 laboratories, with proportions ranging from 1.2 to $32.7 \%$ (mean: $11.5 \%$ ) (Figure 1).

Carbapenem resistance mechanisms in carbapenem-resistant Enterobacteriaceae

Carbapenemase production was detected in the majority of CRE (85\%) (Table 2). KPC-type enzymes were by far the most common $(89.5 \%$ of carbapenemase producers). Other types of carbapenemases included VIM-1 and OXA-48 (9.2\% and $1.3 \%$ of carbapenemase producers, respectively). KPC-type enzymes were only detected in K. pneumoniae and in one E. coli. VIM1 , although much less prevalent, was detected in a wider variety of bacteria: K. pneumoniae, Klebsiella oxytoca, E. coli and Enterobacter cloacae. OXA-48 was only detected in three $K$. pneumoniae isolates (Table 2). KPC-producers were detected in 21 of 25 centres, showing a countrywide distribution. VIM-1-producers were detected in six centres, while the three OXA-48producers were from three different centres (Figure 1). Other types of carbapenemases, including NDM, were not detected. 
TABLE 2

Mechanisms of resistance in carbapenem-nonsusceptible isolates of Enterobacteriaceae, Italy, 15 May-30 June 2011 (n=270)

\begin{tabular}{|l|c|c|c|c|c|c|}
\hline \multirow{2}{*}{ Species } & \multirow{2}{*}{ Isolates } & \multicolumn{4}{c|}{ Carbapenemase } & Non-carbapenemase \\
\cline { 3 - 7 } & & Total (\%) & KPC & VIM-1 & OXA-48 & Total (\%) \\
\hline Escherichia coli & 5 & $2(40.0)$ & 1 & 1 & 0 & $3(60.0)$ \\
\hline Klebsiella pneumoniae & 234 & $223(95.3)$ & 204 & 16 & 3 & $11(4.7)$ \\
\hline Klebsiella oxytoca & 1 & $1(100.0)$ & 0 & 1 & 0 & 0 \\
\hline Enterobacter cloacae & 15 & $3(20.0)$ & 0 & 3 & 0 & $12(80.0)$ \\
\hline Othersa & 15 & 0 & 0 & 0 & 0 & $15(100.0)$ \\
\hline Total & $\mathbf{2 7 0}$ & $\mathbf{2 2 9 ( 8 4 . 8 )}$ & $\mathbf{2 0 5}$ & $\mathbf{2 1}$ & $\mathbf{3}$ & $\mathbf{4 1 ( 1 5 . 2 )}$ \\
\hline
\end{tabular}

a Including Enterobacter aerogenes $(n=6)$, Serratia marcescens $(n=5)$, Proteus mirabilis $(n=1)$, Citrobacter freundii $(n=1)$, and Hafnia alvei $(n=2)$.

\section{Carbapenem-non-susceptible Klebsiella pneumoniae: proportion in clinical specimens, distribution in hospital wards, and carbapenem MICs}

The overall proportion of carbapenem non-susceptibility was approximately seven-fold higher in K. pneumoniae isolates from inpatients than in those from outpatients $(16.3 \%$ versus $2.4 \%$, Table 1$)$. Considering isolates from inpatients, the proportion of carbapenem non-susceptibility was higher among bloodstream isolates than among isolates from other specimens (Table 3), revealing that carbapenem-non-susceptible $K$. pneumoniae strains circulating in Italy retained a remarkable potential for causing invasive infections. In the case of outpatients, carbapenem-non-susceptible isolates of $K$. pneumoniae were obtained only from urine, which was by far the most common specimen, and most of them were KPC-producers (Table 3 ).

Concerning the in-hospital distribution, $42.5 \%$ of the 219 carbapenem-nonsusceptible $K$. pneumoniae from inpatients were from intensive care units (ICUs), while $32.4 \%$ were from medical wards, $21.5 \%$ from surgical wards, and $3.6 \%$ from other areas.

Carbapenem MICs of the 234 carbapenem-nonsusceptible $K$. pneumoniae are reported in Table 4. Virtually all isolates were resistant to ertapenem, while some were intermediate or susceptible to the other carbapenems. A susceptible or intermediate phenotype to imipenem and/or meropenem was observed with most of the VIM producers, with the OXA-48 producers and with the non-carbapenemase producers, while most of the KPC producers were resistant also to these drugs.

Molecular epidemiology and susceptibility to non-betalactam agents of KPC-producing Klebsiella pneumoniae To gather information on the molecular epidemiology of KPC-KP circulating in Italy, the 204 KPC-KP isolates were characterised by MLST and by PFGE genotyping, and their KPC allelic variants were determined by sequencing.

\section{TABLE 3}

Proportions of carbapenem-non-susceptible Klebsiella pneumoniae from different clinical sources, Italy, 15 May-30 June $2011(n=1,346)$

\begin{tabular}{|c|c|c|c|c|}
\hline \multirow[t]{2}{*}{ Source } & \multicolumn{2}{|c|}{ Isolates from inpatients ${ }^{a}$} & \multicolumn{2}{|c|}{ Isolates from outpatients ${ }^{b}$} \\
\hline & Total & CNS-KP (\%) & Total & CNS-KP (\%) \\
\hline Blood & 179 & $40(22.3)$ & 7 & 0 \\
\hline Lower respiratory tract & 219 & $40(18.3)$ & 38 & 0 \\
\hline Urine & 647 & $93(14.4)$ & 503 & $15(3.0)$ \\
\hline Other & 301 & $46(15.3)$ & 70 & 0 \\
\hline Total & 1,346 & $219(16.3)$ & 618 & $15(2.4)$ \\
\hline
\end{tabular}

CNS-KP: carbapenem-non-susceptible Klebsiella pneumoniae.

a Mechanisms of resistance: KPC ( $n=190 ; 86 \%)$ VIM ( $n=15 ; 7 \%)$; OXA-48 $(n=3 ; 2 \%)$; non-carbapenemase producer $(n=11 ; 5 \%)$.

${ }^{\text {b }}$ Mechanisms of resistance: KPC $(n=14 ; 93 \%)$; VIM ( $\left.n=1 ; 7 \%\right)$. 


\begin{tabular}{|c|c|c|c|c|c|c|c|c|c|c|c|c|c|c|c|}
\hline \multirow{2}{*}{$\begin{array}{l}\text { Resistance } \\
\text { mechanism }\end{array}$} & \multicolumn{5}{|c|}{ Meropenem } & \multicolumn{5}{|c|}{ Imipenem } & \multicolumn{5}{|c|}{ Ertapenem } \\
\hline & Range & $\mathrm{MIC}_{50}$ & $\mathrm{MIC9O}$ & $\% \mathrm{~S}$ & $\% R$ & Range & $\mathrm{MIC}_{50}$ & MIC9o & $\% \mathrm{~S}$ & $\% R$ & Range & $\mathrm{MIC}_{50}$ & MIC9o & $\% \mathrm{~S}$ & $\% R$ \\
\hline KPC $(n=204)$ & $\begin{array}{l}4 \text { to } \\
132\end{array}$ & 132 & 132 & 0 & 94 & $\begin{array}{l}4 \text { to } \\
132\end{array}$ & 32 & 132 & 0 & 96 & $\begin{array}{l}16 \text { to } \\
132\end{array}$ & 132 & 132 & 0 & 100 \\
\hline VIM $(n=16)$ & $\begin{array}{l}2 \text { to } \\
132\end{array}$ & 2 & 32 & 62 & 19 & $\begin{array}{l}1 \text { to } \\
132\end{array}$ & 2 & 8 & 50 & 6 & $\begin{array}{l}4 \text { to } \\
132\end{array}$ & 8 & $>32$ & 0 & 100 \\
\hline OXA-48 $(n=3)$ & 1 to 8 & 1 & 1 & 66 & 0 & $\begin{array}{c}0.5 \\
\text { to } 8\end{array}$ & 1 & 1 & 66 & 0 & 132 & 132 & $>32$ & 0 & 100 \\
\hline $\begin{array}{l}\text { Non-carbapenemase } \\
(\mathrm{n}=11)\end{array}$ & $\begin{array}{l}0.25 \\
\text { to } 4\end{array}$ & 0.5 & 1 & 90 & 0 & $\begin{array}{l}0.25 \\
\text { to } 1\end{array}$ & 0.5 & 1 & 100 & 0 & $\begin{array}{l}1 \text { to } \\
132\end{array}$ & 8 & 32 & 0 & 90 \\
\hline Total CPE $(n=223)$ & $\begin{array}{l}1 \text { to } \\
132\end{array}$ & 132 & 132 & 6 & 87 & $\begin{array}{l}0.5 \text { to } \\
32\end{array}$ & 132 & 132 & 5 & 87 & $\begin{array}{l}4 \text { to } \\
232\end{array}$ & 132 & 132 & 0 & 100 \\
\hline TOTAL $(n=234)$ & $\begin{array}{c}0.25 \\
\text { to } \\
132\end{array}$ & 132 & 132 & 10 & 82 & $\begin{array}{c}0.25 \\
\text { to } \\
>32\end{array}$ & 32 & 132 & 10 & 83 & $\begin{array}{l}1 \text { to } \\
\text { >32 }\end{array}$ & 132 & $>32$ & 0 & 99 \\
\hline
\end{tabular}

CPE: carbapenemase-producing Enterobacteriaceae; MIC: minimum inhibitory concentration; R: resistant; S: susceptible.

MICs in $\mathrm{mg} / \mathrm{L}$, interpreted according to EUCAST breakpoints [26]. Percentage of isolates with intermediate susceptibility not shown in the table.

MLST revealed that most isolates belonged in CC 258 , either ST-258 or ST-512 (a single locus variant of ST-258), while a minority were ST-101. ST-258 and ST-512 isolates were detected in many centres, with an overall countrywide distribution, while ST-101 isolates were detected in only two centres, where ST-512 was also present (Figure 2). Isolates of ST-258 carried either bla KPC.2 $_{2}$ or bla $\mathrm{KPC} .3_{3}$ alleles, while those of ST-512 and of ST-101 carried bla $\mathrm{KPC}-3_{3}$ and bla $\mathrm{K}_{\mathrm{KPC}-2}$, respectively (Figure 2).

PFGE genotyping revealed an oligoclonal population of KPC-KP, with a prevalent PFGE profile, named A, consisting of several variants (Ao to $A 6$ ) and including the isolates of $\mathrm{CC}-258$. In particular, the $\mathrm{Ao}_{0} \mathrm{~A}_{4}$ and $\mathrm{A}_{5}$ variants included isolates of ST-512 producing KPC-3, while the $A_{1}$ and $A_{2}$ variants included isolates of ST-258 producing KPC-3, and the $A_{3}$ and $A 6$ variants included isolates of ST-258 producing KPC-2 (Figure 2). Each variant was detected in multiple centres (Figure 2), confirming the epidemic propensity of this lineage. An additional PFGE profile, named $B$ and consisting of only a few variants (Bo to $B 2$ ), included the isolates of ST-101 producing KPC-2 and was detected in two centres (Figure 2).

Susceptibility testing of the 204 KPC-KP against non-beta-lactam agents which often retain activity against these strains, revealed that $22.4 \%$ were resistant to colistin, $20.9 \%$ were non-susceptible to tigecycline, and $15.8 \%$ were non-susceptible to gentamicin. Concerning co-resistances, $1.5 \%$ of the KPC-KP were non-susceptible to all three drugs, while $6.4 \%$ were non-susceptible to tigecycline and colistin, $1 \%$ to gentamicin and colistin, and $2.7 \%$ to tigecycline and gentamicin. No association was detected between ST and non-susceptibility to colistin or tigecycline, while non-susceptibility to gentamicin was more frequent in isolates of ST-101 $(85.8 \%$ versus $12.6 \%$ in ST-258 or $10 \%$ in ST-512, p $<0.05)$.

\section{Discussion}

A rapid dissemination of carbapenem-non-susceptible K. pneumoniae has been reported in Italy since 2010 $[10,24]$. Results of this cross-sectional survey, carried out in mid-2011, confirmed that CRE have undergone an epidemic diffusion in Italy, with a widespread distribution across the national territory (although with variable proportions in different areas), and that the phenomenon was mostly related with rapid dissemination of carbapenem-non-susceptible $K$. pneumoniae, while the contribution by CRE of other enterobacterial species was much more limited.

Production of KPC-type carbapenemases was the most prevalent carbapenem resistance mechanism. Production of other carbapenemases and non-carbapenemase-mediated mechanisms were also detected, but remained in the background. However, continuous surveillance should be enforced, considering a recent outbreak caused by NDM-1-producing $K$. pneumoniae [18].

Expansion of KPC-KP strains belonging to variants (ST258 and ST-512) of the hyperepidemic CC-258, detected for the first time in Italy in late 2008 [13], was responsible for a major part of the CRE epidemic in Italy. A similar 
PFGE

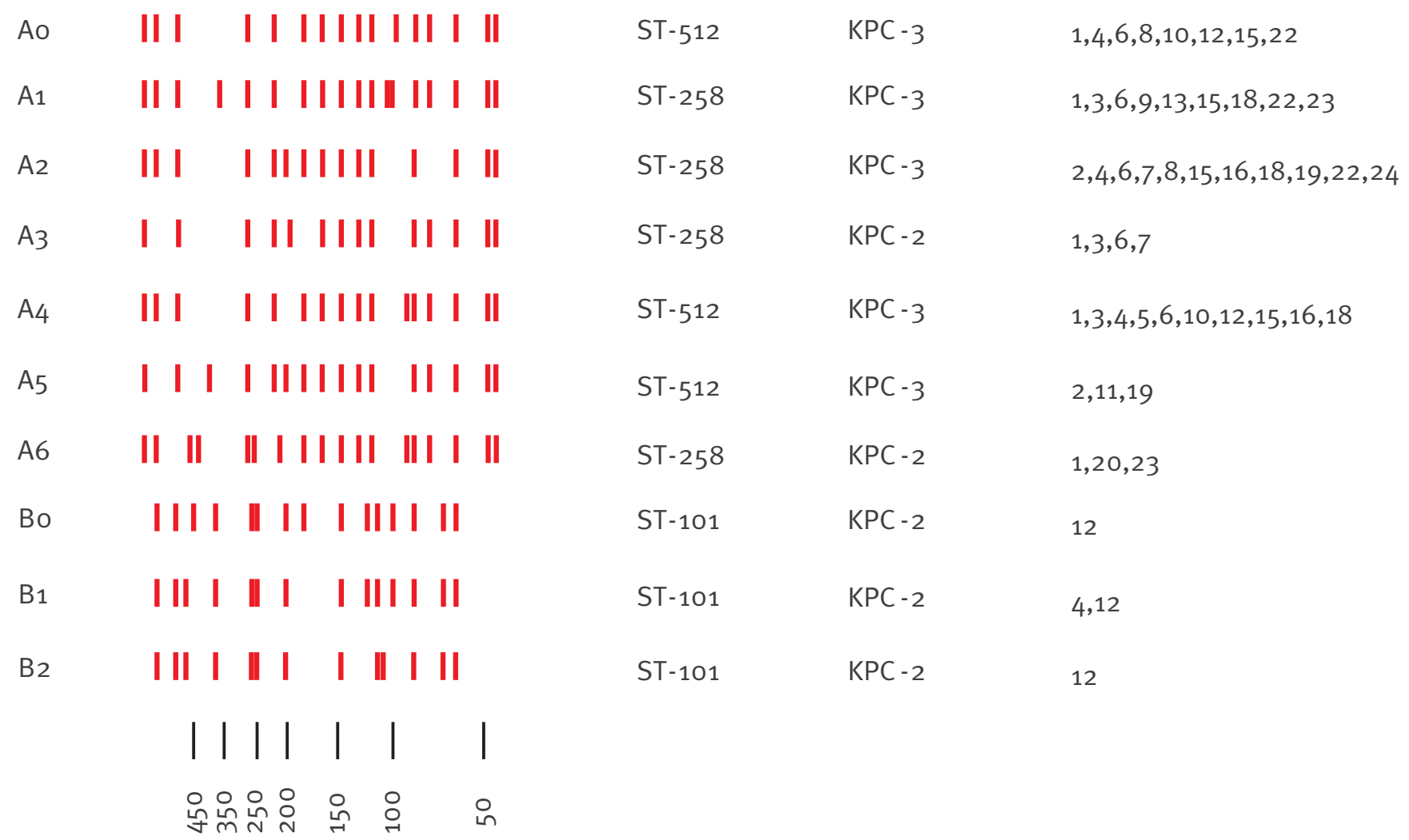

PFGE: pulsed-field gel electrophoresis; KPC-KP: KPC-type carbapenemase-producing Klebsiella pneumoniae; MLST: multi-locus sequence typing.

DNA size standards for PFGE profiles are indicated at the bottom. Distribution by centres of different PFGE-types is also indicated: 1 : Milan; 2: Varese; 3: Lecco; 4: Turin; 5: Novara; 6: Genoa; 7: Sanremo; 8: Verona; 9: Bolzano; 10-11: Modena; 12: Florence; 13: Siena; 14: Perugia; 15: Ancona; 16: Rome; 17: Pescara; 18: San Giovanni Rotondo; 19: Lecce; 20: Naples; 21: Avellino; 22: Cosenza; 23: Palermo; 24-25: Catania.

phenomenon was also observed in other countries and further underscores the propensity for dissemination of multi-resistant $K$. pneumoniae strains belonging to ST-258 and ST-512 [40-47]. Emergence of KPC-KP belonging to ST-101 was also observed, although only in two of the participating centres. This finding, along with recent reports of ST-101 isolates of KPC-KP from Italy, Brazil and the United States [21,42,48,49], emphasises the emerging role in dissemination of KPC of this clonal lineage which is also involved in the dissemination of other carbapenemases, such as OXA48 and OXA-181 $[50,51]$ as well as extended-spectrum beta-lactamases $[52,53]$.

Since aggressive infection control was shown to be effective in controlling the dissemination of KPC-KP [54-56], present results mandate for strong and prompt intervention in Italy. Implementation of infection control measures on a countrywide scale appears now to be necessary, in addition to the actions that have already been taken at local and regional level (the Italian public healthcare system has a typically regional organisation) with positive results. In a hospital in Catania, Sicily, it was possible to control the spread of a KPC-3-producing $K$. pneumoniae clone without closing the ICU, by applying a multimodal infection control programme [16]. The Emilia-Romagna region issued in July 2011 guidelines and protocols to monitor and control the spread of carbapemenase-producing Enterobacteriaceae in all the healthcare structures of the region. The increasing trend of KPC-producing K. pneumoniae slowed down in the second half of 2011 and early 2012, and in hospitals that had been able to implement all control activities the number of cases had a remained stable or showed a sustained decrease [57]. Dissemination of carbapenem-non-susceptible $K$. pneumoniae was not restricted to ICU settings, but affected all major hospital sectors. Although at least some of these patients could have been transferred from ICU settings, this propensity to dissemination on 
multiple wards should be considered when planning infection control strategies.

Although cases and outbreaks of CRE have been reported in many European countries [6], only Greece, Cyprus and Italy have experienced such an extensive CRE epidemic to date. However, the phenomenon observed in these countries deserves considerable attention by public health authorities in Europe, considering the high mobility of people (tourists, workers, patients) within Europe, and the difficulties in containing the epidemic diffusion of CRE.

\section{Acknowledgements}

This work was partially supported by a research grant from Pfizer to $A M C L I$, and by a grant from $\mathrm{FP}_{7}$ projects TEMPOTEST-QC (no. HEALTH-2009-241742) from TROCAR (no. HEALTH-F3-2008-223031) and from EvoTAR (no. HEALTH-F3-2011-2011-282004) to G.M.R. The contribution of bioMérieux and Becton Dickinson in supporting the transport of isolates from the collecting laboratories to the reference laboratories is gratefully acknowledged.

Participants of the AMCLI-CRE Survey (the first Italian survey on carbapenem-resistant Enterobacteriaceae, promoted by the Italian Society of Clinical Microbiologists)

Milan, Niguarda Ca' Granda Hospital - C. Vismara; Varese, Circolo and Fondazione Macchi University Hospital - A. Colombo; Turin, S. Giovanni Battista "Molinette" Hospital R. Serra; Lecco, A. Manzoni Hospital - F. Luzzaro; Novara, Maggiore Hospital - V. Kroumova; Genoa, Galliera Hospital M. Mori; Sanremo, Azienda Sanitaria Imperiese Hospital - P. A. Dusi; Verona, Borgo Roma University Hospital - A. Mazzariol; Bolzano, Azienda Sanitaria dell'Alto Adige Hospital - E. Pagani; Modena, S. Agostino Estense Hospital - R. Gargiulo; Modena, Modena University Hospital - C. Venturelli; Firenze, Careggi University Hospital - P. Pecile; Siena, Santa Maria alle Scotte University Hospital - G.M. Rossolini; Perugia, Santa Maria della Misericordia University Hospital - A. Mencacci; Ancona, "Torrette" University Hospital - E. Manso; Rome, San Camillo Forlanini Hospital - M. Tronci; Pescara, Santo Spirito Hospital - P. Fazii; San Giovanni Rotondo, IRCCS Casa Sollievo della Sofferenza Hospital - M. Labonia; Lecce, V. Fazzi Hospital - M. Pizzolante; Neaples, A. Cardarelli Hospital - G. Amato; Avellino, San Giuseppe Moscati Hospital - G. Buonopane; Cosenza, Annunziata Hospital - P. Cavalcanti; Palermo, Mediterranean Institute of Transplantation (ISMETT) - P.G. Conaldi; Catania, Policlinico and Vittorio Emanuele University Hospitals - S. Stefani; Catania, Policlinico Hospitals - F. Di Vincenzo.

\section{References}

1. Grundmann H, Livermore DM, Giske CG, Canton R, Rossolini GM, Campos \}, et al. Carbapenem-non-susceptible Enterobacteriaceae in Europe: conclusions from a meeting of national experts. Euro Surveill. 2010;15(46):pii=19711. Available from: http://www.eurosurveillance.org/ViewArticle. aspx?Articleld=19711. PMid:21144429.

2. Nordmann P, Dortet L, Poirel L. Carbapenem resistance in Enterobacteriaceae: here is the storm! Trends Mol Med. 2012;18(5):263-72. http://dx.doi.org/10.1016/j. molmed.2012.03.003. PMid:22480775.

3. Hirsch EB, Tam VH. Detection and treatment options for Klebsiella pneumoniae carbapenemases (KPCs): an emerging cause of multidrug-resistant infection. J Antimicrob Chemother. 2010; 65(6):1119-25. http://dx.doi.org/10.1093/jac/dkq108. PMid:20378670.

4. Falagas ME, Karageorgopoulos DE, Nordmann P. Therapeutic options for infections with Enterobacteriaceae producing carbapenem-hydrolyzing enzymes. Future Microbiol 2011;6(6):653-66. http://dx.doi.org/10.2217/fmb.11.49. PMid:21707312.

5. Borer A, Saidel-Odes L, Riesenberg K, Eskira S, Peled N, Nativ R, et al. Attributable mortality rate for carbapenemresistant Klebsiella pneumoniae bacteremia. Infec. Control Hosp Epidemiol. 2009;30(10): 972-6. http://dx.doi. org/10.1086/605922. PMid:19712030.

6. Canton R, Akova M, Carmeli Y, Giske CG, Glupczynski Y, Gniadkowski M, et al. Rapid evolution and spread of carbapenemases among Enterobacteriaceae in Europe. Clin Microbiol Infect. 2012;18(5):413-31. http://dx.doi.org/10.1111/ j.1469-0691.2012.03821.x. PMid:22507109.

7. Nordmann P, Naas T, Poirel L. Global spread of carbapenemase-producing Enterobacteriaceae. Emerg Infect Dis. 2011;17(10):1791-8. http://dx.doi.org/10.3201/ eid1710.110655. PMid:22000347. PMCid:3310682.

8. Cornaglia G, Giamarellou H, Rossolini GM. Metallo- $\beta$ lactamases: a last frontier for beta-lactams? Lancet Infect Dis. 2011;11(5):381-93. http://dx.doi.org/10.1016/ S1473-3099(11)70056-1.

9. Poirel L, Potron A, Nordmann P. OXA-48-like carbapenemases: the phantom menace. J Antimicrob Chemother. 2012;67(7):1597606. http://dx.doi.org/10.1093/jac/dks121. PMid:22499996.

10. European Centre for Disease Prevention and Control (ECDC). Antimicrobial resistance surveillance in Europe 2011. Annual Report of the European Antimicrobial Resistance Surveillance Network (EARS-Net). Stockholm: ECDC; 2012. Available from: http://www.ecdc.europa.eu/en/publications/Publications/ antimicrobial-resistance-surveillance-europe-2011.pdf

11. Luzzaro F, Docquier JD, Colinon C, Endimiani A, Lombardi G, Amicosante G, et al. Emergence in Klebsiella pneumoniae and Enterobacter cloacae clinical isolates of the VIM-4 metallo-beta-lactamase encoded by a conjugative plasmid. Antimicrob Agents Chemother. 2004;48(2):648-50. http:// dx.doi.org/10.1128/AAC.48.2.648-650.2004. PMid:14742229. PMCid:321512.

12. Cagnacci S, Gualco L, Roveta S, Mannelli S, Borgianni L, Docquier JD, et al. Bloodstream infections caused by multidrug-resistant Klebsiella pneumoniae producing the carbapenem-hydrolysing VIM-1 metallo-beta-lactamase: first Italian outbreak. J Antimicrob Chemother. 2008;61(2):296-300. http://dx.doi.org/10.1093/jac/dkm471. PMid:18065411.

13. Giani T, D’Andrea MM, Pecile P, Borgianni L, Nicoletti P, Tonelli $\mathrm{F}$, et al. Emergence in Italy of Klebsiella pneumoniae sequence type 258 producing KPC-3 carbapenemase. J Clin Microbiol. 2009;47(11):3793-4. http://dx.doi.org/10.1128/JCM.01773-09. PMid:19759220. PMCid:2772625.

14. Fontana C, Favaro M, Sarmati L, Natoli S, Altieri A, Bossa MC, et al. Emergence of KPC-producing Klebsiella pneumoniae in Italy. BMC Res Notes. 2010;3:40, http://dx.doi. org/10.1186/1756-0500-3-40. PMid:20178590. PMCid:2844393.

15. Mammina C, Palma DM, Bonura C, Anna Plano MR, Monastero R, Sodano C, et al. Outbreak of infection with Klebsiella pneumoniae sequence type 258 producing Klebsiella pneumoniae carbapenemase 3 in an intensive care unit in Italy. J Clin Microbiol. 2010;48(4):1506-7. http://dx.doi.org/10.1128 JCM.00315-10. PMid:20200298. PMCid:2849560.

16. Agodi A, Voulgari E, Barchitta M, Politi L, Koumaki V, Spanakis N, et al. Containment of an outbreak of KPC-3. producing Klebsiella pneumoniae in Italy. I Clin Microbiol. 2011;49(11):3986-9. http://dx.doi.org/10.1128/JCM.01242-11. PMid:21900525. PMCid:3209099.

17. Aschbacher R, Pagani L, Doumith M, Pike R, Woodford $\mathrm{N}$, Spoladore G, et al. Metallo-beta-lactamases among Enterobacteriaceae from routine samples in an Italian tertiarycare hospital and long-term care facilities during 2008. Clin 
Microbiol Infect. 2011;17(2):181-9. http://dx.doi.org/10.1111/ j.1469-0691.2010.03225.x. PMid:20345467.

18. Gaibani P, Ambretti S, Berlingeri A, Cordovana M, Farruggia $P$, Panico $M$, et al. Outbreak of NDM-1-producing Enterobacteriaceae in northern Italy, July to August 2011. Euro Surveill. 2011;16(47):pii=20027. Available from: http://www. eurosurveillance.org/ViewArticle.aspx?Articleld=20027

19. Gaibani P, Ambretti S, Berlingeri A, Gelsomino F, Bielli A, Landini MP, et al. Rapid increase of carbapenemase-producing Klebsiella pneumoniae strains in a large Italian hospital: surveillance period 1 March - 30 September 2010. Euro Surveill. 2011;16(8):pii=19800. Available from: http://www. eurosurveillance.org/ViewArticle.aspx?Articleld =19800

20. Mezzatesta ML, Gona F, Caio C, Petrolito V, Sciortino D, Sciacca $\mathrm{A}$, et al. Outbreak of KPC-3-producing, and colistin-resistant, Klebsiella pneumoniae infections in two Sicilian hospitals. Clin Microbiol Infect. 2011;17(9):1444-7. PMid:21668577.

21. Mammina $C$, Bonura $C$, Aleo A, Fasciana T, Brunelli T, Pesavento G, et al. Sequence type 101 (ST101) as the predominant carbapenem-non-susceptible Klebsiella pneumoniae clone in an acute general hospital in Italy. Int J Antimicrob Agents. 2012; 39(6):543-5. http://dx.doi. org/10.1016/j.ijantimicag.2012.02.012 PMid:22534506.

22. Orsi GB, Bencardino A, Vena A, Carattoli A, Venditti C, Falcone $M$, et al. Infection-patient risk factors for outer membrane permeability and KPC-producing carbapenem resistant Klebsiella pneumoniae isolation: results of a double casecontrol study. Infection. 2013; 41(1):61-7. http://dx.doi. org/10.1007/S15010-012-0354-2. PMid:23070604.

23. Richter SN, Frasson I, Franchin E, Bergo C, Lavezzo E, Barzon L, et al. KPC-mediated resistance in Klebsiella pneumoniae in two hospitals in Padua, Italy, June 2009-December 011: massive spreading of a KPC-3-encoding plasmid and involvement of non-intensive care units. Gut Pathog. 2012; 4(1):7. http://dx.doi.org/10.1186/1757-4749-4-7. PMid:22800501. PMCid:3411510.

24. Capone A, Giannella M, Fortini D, Giordano A, Meledandri $M$, Ballardini $M$, et al. High rate of colistin resistance among patients with carbapenem-resistant Klebsiella pneumoniae infection accounts for an excess of mortality. Clin Microbiol Infect. 2013;19(1):E23-E30. http://dx.doi.org/10.1111/14690691.12070. PMid:23137235.

25. Sisto A, D’Ancona F, Meledandri M, Pantosti A, Rossolini GM, Raglio A, et al. Carbapenem non-susceptible Klebsiella pneumoniae from Micronet network hospitals, Italy, 2009 to 2012. Euro Surveill. 2012;17(33): $\mathrm{pii}=20247$. Available from: http://www.eurosurveillance.org/ViewArticle. aspx?Articleld=20247. PMid:22913976.

26. The European Committee on Antimicrobial Susceptibility Testing (EUCAST) [Internet]. Breakpoint tables for interpretation of MICs and zone diameters. Version 3.1. 11 Feb 2013.Avaible from: http://www.eucast.org/fileadmin/ src/media/PDFs/EUCAST_files/Breakpoint_tables/ Breakpoint_table_v_3.1.p df

27. Clinical Laboratory Standards Institute (CLSI). Methods for dilution antimicrobial susceptibility. Tests for bacteria that grow aerobically; Approved standars. Ninth edition. CLSI document Mo7-A9. Wayne, PA: CLSI. 2012.

28. Giske CG, Gezelius L, Samuelsen O, Warner M, Sundsfjord A, Woodford N. A sensitive and specific phenotypic assay for detection of metallo-beta-lactamases and KPC in Klebsiella pneumoniae with the use of meropenem disks supplemented with aminophenylboronic acid, dipicolinic acid and cloxacillin. Clin Microbiol Infect. 2011;17(4):552-6. http://dx.doi. org/10.1111/j.1469-0691.2010.03294.x. PMid:20597925.

29. Tsakris A, Poulou A, Pournaras S, Voulgari E, Vrioni G, Themeli-Digalaki K, et al. A simple phenotypic method for the differentiation of metallo-beta-lactamases and class A KPC carbapenemases in Enterobacteriaceae clinical isolates. J Antimicrob Chemother. 2011;65(8):1664-71. http://dx.doi. org/10.1093/jac/dkq210. PMid:20542902.

30. Srinivasan U, Zhang L, France AM, Ghosh D, Shalaby W, Xie J, et al. Probe hybridization array typing: a binary typing method for Escherichia coli. J Clin Microbiol. 2007;45(1):20614. http://dx.doi.org/10.1128/JCM.01543-06. PMid:17079499. PMCid:1828955.

31. D’Andrea MM, Giani T, D’Arezzo S, Capone A, Petrosillo $\mathrm{N}$, Visca $\mathrm{P}$, et al. Characterization of pABVAo1, a plasmid encoding the OXA-24 carbapenemase from Italian isolates of Acinetobacter baumannii. Antimicrob Agents Chemother. 2009;53(8):3528-33. http://dx.doi.org/10.1128/AAC.00178-09. PMid:19487447. PMCid:2715606.

32. D’Andrea MM, Venturelli C, Giani T, Arena F, Conte V, Bresciani $P$, et al. Persistent carriage and infection by multidrug-resistant Escherichia coli ST405 producing NDM-1 carbapenemase: report on the first Italian cases. J Clin Microbiol.
2011;49(7):2755-8. http://dx.doi.org/10.1128/JCM.00016-11. PMid:21525229. PMCid:3147842.

33. Giani T, Conte V, Di Pilato V, Aschbacher R, Weber C, Larcher $C$, et al. Escherichia coli from Italy producing OXA-48 carbapenemase encoded by a novel Tn1999 transposon derivative. Antimicrob Agents Chemother. 2012;56(4):2211-3. http://dx.doi.org/10.1128/AAC.00035-12. PMid:22290939. PMCid:3318333.

34. Lee K, Chong Y, Shin HB, Kim YA, Yong D, Yum JH. Modified Hodge and EDTA-disk synergy tests to screen metallobeta-lactamase-producing strains of Pseudomonas and Acinetobacter species. Clin Microbiol Infect. 2001;7(2):88 91. http://dx.doi.org/10.1046/j.1469-0691.2001.00204.x. PMid:11298149.

35. Lauretti L, Riccio ML, Mazzariol A, Cornaglia G, Amicosante $\mathrm{G}$, Fontana R, et al. Cloning and characterization of blaVIM, a new integron-borne metallo-beta-lactamase gene from a Pseudomonas aeruginosa clinical isolate. Antimicrob Agents Chemother. 1999;43(7):1584-90. PMid:10390207. PMCid:89328.

36. Yuan M, Aucken H, Hall LM, Pitt TL, Livermore DM. Epidemiological typing of Klebsiellae with extended-spectrum beta-lactamases from European intensive care units. J Antimicrob Chemother. 1998;41(5):527-39. http://dx.doi. org/10.1093/jac/41.5.527. PMid:9630406.

37. Van Belkum A, Tassios PT, Dijkshoorn L, Haeggman S, Cookson $B$, Fry NK, et al. Guidelines for the validation and application of typing methods for use in bacterial epidemiology. Clin Microbiol Infect. 2007;13 Suppl 3:1-46. http://dx.doi. org/10.1111/j.1469-0691.2007.01786.x. PMid:17716294.

38. Diancourt L, Passet V, Verhoef J, Grimont PA, Brisse S. Multilocus sequence typing of Klebsiella pneumoniae nosocomial isolates. J Clin Microbiol. 2005;43(8):417882. http://dx.doi.org/10.1128/JCM.43.8.4178-4182.2005. PMid:16081970. PMCid:1233940.

39. Institut Pasteur. Klebsiella pneumoniae MLST Database. Paris: Institut Pasteur. [Accessed Dec 2011]. Available from: http:// www.pasteur.fr/recherche/genopole/PF8/mlst/Kpneumoniae. html

40. Baraniak A, Izdebski R, Herda M, Fiett J, Hryniewicz W, Gniadkowski M, et al. Emergence of Klebsiella pneumoniae ST258 with KPC-2 in Poland. Antimicrob Agents Chemother. 2009; 53(10):4565-7. http://dx.doi.org/10.1128/AAC.00436-09. PMid:19620323. PMCid:2764197.

41. Giakkoupi P, Maltezou H, Polemis M, Pappa O, Saroglou G, Vatopoulos A, et al. KPC-2-producing Klebsiella pneumoniae infections in Greek hospitals are mainly due to a hyperepidemic clone. Euro Surveill. 2009;14(21):pii=19218. Available from: http://www.eurosurveillance.org/ViewArticle. aspx?Articleld $=19218$

42. Kitchel B, Rasheed JK, Patel JB, Srinivasan A, Navon-Venezia S, Carmeli Y, et al. Molecular epidemiology of KPC-producing Klebsiella pneumoniae isolates in the United States: clonal expansion of multilocus sequence type 258. Antimicrob Agents Chemother. 2009;53(8):3365-70. http://dx.doi.org/10.1128/ AAC.00126-09. PMid:19506063. PMCid:2715580.

43. Navon-Venezia S, Leavitt A, Schwaber MJ, Rasheed JK, Srinivasan A, Patel JB, et al. First report on a hyperepidemic clone of KPC-3-producing Klebsiella pneumoniae in Israel genetically related to a strain causing outbreaks in the United States. Antimicrob Agents Chemother. 2009;53(2):818-20. http://dx.doi.org/10.1128/AAC.00987-08. PMid:19029323. PMCid:2630632.

44. Bogaerts P, Montesinos I, Rodriguez-Villalobos H, Blairon L, Deplano A, Glupczynski Y. Emergence of clonally related Klebsiella pneumoniae isolates of sequence type 258 producing KPC-2 carbapenemase in Belgium. J Antimicrob Chemother. 2010;65(2):361-2. http://dx.doi.org/10.1093/jac/ dkp453. PMid:20008447.

45. Cuzon G, Naas T, Truong H, Villegas MV, Wisell KT, Carmeli Y, et al. Worldwide diversity of Klebsiella pneumoniae that produce beta-lactamase blaKPC-2 gene. Emerg Infect Dis. 2010;16(9):1349-56. http://dx.doi.org/10.3201/eid1609.091389. PMid:20735917. PMCid:3294963.

46. Andrade LN, Curiao T, Ferreira JC, Longo JM, Climaco EC, Martinez R, et al. Dissemination of blaKPC-2 by the spread of Klebsiella pneumoniae clonal complex 258 clones (ST258, ST11, ST437) and plasmids (IncFII, IncN, IncL/M) among Enterobacteriaceae species in Brazil. Antimicrob Agents Chemother. 2011;55(7):3579-83. http://dx.doi.org/10.1128/ AAC.01783-10. PMid:21576442. PMCid:3122403.

47. Warburg G, Hidalgo-Grass C, Partridge SR, Tolmasky ME, Temper V, Moses AE, et al. A carbapenem-resistant Klebsiella pneumoniae epidemic clone in Jerusalem: sequence type 512 carrying a plasmid encoding aac(6')-lb. J Antimicrob Chemother. 2012;67(4):898-901. http://dx.doi.org/10.1093/ jac/dkr552. PMid:22287232. 
48. Frasson I, Lavezzo E, Franchin E, Toppo S, Barzon L, Cavallaro $A$, et al. Antimicrobial treatment and containment measures for an extremely drug-resistant Klebsiella pneumoniae ST101 isolate carrying pKPN101-IT, a novel fully sequenced bla(KPC-2) plasmid. J Clin Microbiol. 2012;50(11):3768-72. http://dx.doi. org/10.1128/JCM.01892-12. PMid:22972824. PMCid:3486238.

49. Seki LM, Pereira PS, de Souza Mda P, Conceição S, Marques EA, Porto CO, et al. Molecular epidemiology of KPC-2-producing Klebsiella pneumoniae isolates in Brazil: the predominance of sequence type 437. Diagn Microbiol Infect Dis. 2011;70(2):274-7. http://dx.doi.org/10.1016/j. diagmicrobio.2011.01.006. PMid:21397425.

50. Österblad M, Kirveskari J, Hakanen AJ, Tissari P, Vaara M, Jalava J. Carbapenemase-producing Enterobacteriaceae in Finland: the first years (2008-11). J Antimicrob Chemother. 2012; 67(12):2860-4. http://dx.doi.org/10.1093/jac/dks299. PMid:22855858.

51. Pitart C, Solé M, Roca I, Fàbrega A, Vila J, Marco F. First outbreak of a plasmid-mediated carbapenem-hydrolyzing OXA-48 beta-lactamase in Klebsiella pneumoniae in Spain. Antimicrob Agents Chemother. 2011;55(9):4398-401. http://dx.doi.org/10.1128/AAC.00329-11. PMid:21746954. PMCid:3165339.

52. Ma L, Lu PL, Siu LK, Hsieh MH. Molecular typing and resistance mechanisms of imipenem-non-susceptible Klebsiella pneumoniae in Taiwan: results from the Taiwan surveillance of antibiotic resistance (TSAR) study, 2002-2009. J Med Microbiol. 2013;62(Pt 1):101-7. http://dx.doi.org/10.1099/jmm.0.050492o. PMid:23002067.

53. Marcade G, Brisse S, Bialek S, Marcon E, Leflon-Guibout $\mathrm{V}$, Passet V, et al. The emergence of multidrug-resistant Klebsiella pneumoniae of international clones ST13, ST16, ST35, ST48 and ST101 in a teaching hospital in the Paris region. Epidemiol Infect. 2012; 4:1-8. http://dx.doi.org/10.1017/ So950268812002099. PMid:23034125.

54. Carbonne A, Thiolet JM, Fournier S, Fortineau N, KassisChikhani N, Boytchev I, et al. Control of a multi-hospital outbreak of KPC-producing Klebsiella pneumoniae type 2 in France, September to October 2009. Euro Surveill. 2010;15(48):pii=19734. Available from: http://www. eurosurveillance.org/ViewArticle. aspx?Articleld=19734

55. Schwaber MJ, Lev B, Israeli A, Solter E, Smollan G, Rubinovitch B, et al. Containment of a country-wide outbreak of carbapenem-resistant Klebsiella pneumoniae in Israeli hospitals via a nationally implemented intervention. Clin Infect Dis. 2011;52(7):848-55. http://dx.doi.org/10.1093/cid/ciro25. PMid:21317398.

56. Landman D, Babu E, Shah N, Kelly P, Olawole O, Backer M, et al. Transmission of carbapenem-resistant pathogens in New York City hospitals: progress and frustration. J Antimicrob Chemother. 2012;67(6):1427-31. http://dx.doi.org/10.1093/jac/ dks063. PMid:22378678.

57. Agenzia Sanitaria e sociale regionale. Indicazioni pratiche e protocolli operativi per la diagnosi, la sorveglianza e il controllo degli enterobatteri produttori di carbapenemasi nelle strutture sanitarie e socio-sanitarie. [Practical guidance and operational protocols for the diagnosis, surveillance and control of carbapenemase-producing Enterobacteriaceae in health and social care settings]. Jan 2013. Italian. Available from: http://assr.regione.emilia-romagna.it/it/servizi/ pubblicazioni/rapporti-documenti/copy_of_indicazionipratiche-e-protocolli-operativi-per-la-diagnosi-la-sorveglianzae-il-controllo-degli-enterobatteri-produttori-di-carbapenemasinelle-strutture-sanitarie-e-socio-sanitarie 